\begin{tabular}{|c|c|c|}
\hline Beitr. Ent. & Berlin & ISSN 0005-805X \\
\hline $48(1998) 2$ & S. 531-537 & 05.10 .1998 \\
\hline
\end{tabular}

\title{
On the taxonomy of two German pipunculid flies with remarks on the terminology of the male genitalia
}

\section{(Diptera)}

With 3 figures

\section{MARTIN DEMPEWOLF}

\section{Summary}

Eudorylas vonderdunki spec. $\mathrm{n}$. is described and compared with the related E. subfascipes CoLLIN, 1956. The previously unknown male of Chalarus decorus JERVIS, 1992 is described, distinguishing characters are indicated, and the key of male Chalarus spp. by JeRVIS (1992) is amended. The terminology of male terminalia used for pipunculids is discussed.

\section{Zusammenfassung}

Eudorylas vonderdunki spec. n. wird beschrieben und mit der verwandten Art E. subfascipes ColLIN, 1956 verglichen. Für das bisher unbekannte Männchen von Chalarus decorus JERVIS, 1992 werden Bestimmungsmerkmale geliefert sowie eine Ergänzung des Schlüssels von JERVIS (1992) vorgenommen. Die Terminologie der männlichen Genitalien von Pipunculiden wird diskutiert.

\section{Introduction}

In the last years the parasitoid fly family Pipunculidae was object of increasing attention by entomologists, several new central European species were described. This is due to the widespread use of automatic traps that makes great amounts of specimens available.

Since there is some confusion concerning names of the hypandrial complex and aedeagus I intend to propose a terminology which is both, practical and compatible with that of other dipteran families. This will be applied on the descriptions in this paper.

The genus Chalarus WALKER, 1834, well characterised by the reduced wing venation, belongs to the rather plesiomorphic subfamily Chalarinae and bears great taxonomical difficulties because of small size of all species and the great uniformity of even their male terminalia. They are all parasitoids of typhlocybine leafhoppers (Cicadellidae, Typhlocybinae) and occur in the surrounding area of their hosts' foodplants which are mainly trees and shrubs. Because in this area sweep net sampling and running traps is more difficult, there are less frequently collected than open land species. In his revision JERVIS (1992) listed 38 ascertained species, of these 21 from Europe. Many undescribed species should be expected worldwide.

In contrast to Chalarus, the species rich genus Eudorylas ACZÉL, 1949 within the subfamily Pipuculinae shows a remarkable variety of forms particularly regarding the male genitalia. In Germany 37 species are recorded so far. Many new species from various zoogeographical regions were described recently. The main difficulty in the taxonomy of Eudorylas is that older 
descriptions and keys do not contain sufficiently detailed diagnostical features and drawings so in some cases neither already described species could be identified nor undescribed species could be detected. Eudorylas vonderdunki spec. nov. is an example for such difficulties. It can be easily separated from the closely related $E$. subfascipes CoLLIN, 1956 by characters of the male terminalia, provided, a collection of both species or figures do exist. For this reason I figure the male genitalia of both species to illustrate the main differences of these related species.

\section{On the terminology of parts of the male genitalia}

Most species of the more derived subfamily Pipunculinae (an exception is Eudorylas clavatus (BECKER, 1898) see DEMPEWOLF 1996) exhibit a hypandrial appendix presumably directing the aedeagus at copulation and protecting while it is resting. Although it does not take part in the sperm transfer directly, the high taxonomic value of this organ especially in the case of Eudorylas spp. indicates, however, its further importance for courtship and success of copulation. Previous authors (e.g. DE MEYER 1989, ALBRECHT 1992) called it aedeagus but I don't share this opinion since no junction to the sperm pump or other parts of the gonads exists. RAFAEL (1991) holds the view that this appendix consists of parameres and referred in this respect to the Manual of Nearctic Diptera (MCALPINE et al. 1981). In this work MCALPINE described in the second chapter the parameres as articulating "the base of the aedeagus and the dorsomedial base of each gonocoxite." In the Syrphidae, which is known as the plausible sister group of Pipunculids, the parameres in accordance to MCALPINE are clearly branching just before the base of the distiphallus. They are presumable also present at the pipunculid subfamilies Nephrocerinae and Chalarinae, (MORAKote \& HIRASHIMA 1990 a, Fig. 1a) but obviously vanished in all known species of the subfamily Pipunculinae.

For this reasons the name 'aedeagal guide' should be applied to the organ, shown in fig. $3 \mathrm{~d}$,e because it is compatible to the terminology of MCALPINE (p. 49) and reflects the probable function of the this taxonomic important organ. MORAKOTE \& HIRASHIMA (1990b) seem to have a similar opinion, they used 'aedeagal supporter', but the elder name 'aedeagal guide' has priority. The name 'ejaculatory duct' was applied to the actual aedeagus (ALBRECHT 1990, p. 60,61 ), but only in the subfamily Pipunculinae where the term 'aedeagus' was occupied. In the case of the species of Chalarinae, which do not have an aedeagal guide, the name aedeagus was used correctly.

The concept ${ }^{-}$of the parts of male terminalia and their nomenclature, e.g. the parameres and epandrium, are object of controversy between many workers (see CUMMING et al. 1995, GRIFFITHS 1996). Some terms will become obsolete soon if advances in research increase the knowledge on the homology of male terminalia in Diptera. The aim of my discussion is only to resolve the contradictions within the family Pipunculidae.

\section{Systematic account}

\section{Chalarus decorus JERVIS, 1992}

(Fig. 1)

My recent studies on pipunculids show that Chalarus decorus is one of the most widespread species of the genus in Germany. The previously unknown male (JERVIS 1992) was identified from malaise trap material obtained 1990 and 1991 in the vicinity of an old quarry surrounded by calcareous grass land (DEMPEWOLF \& CöLLN 1995). In these traps both $C h$. decorus and the related Ch. spurius (FALLÉN, 1816) were fairly abundant so the differences between both species could be detected. In the following diagnosis JERVIS' (1992: 322) terminology for parts of the aedeagus is adopted. 


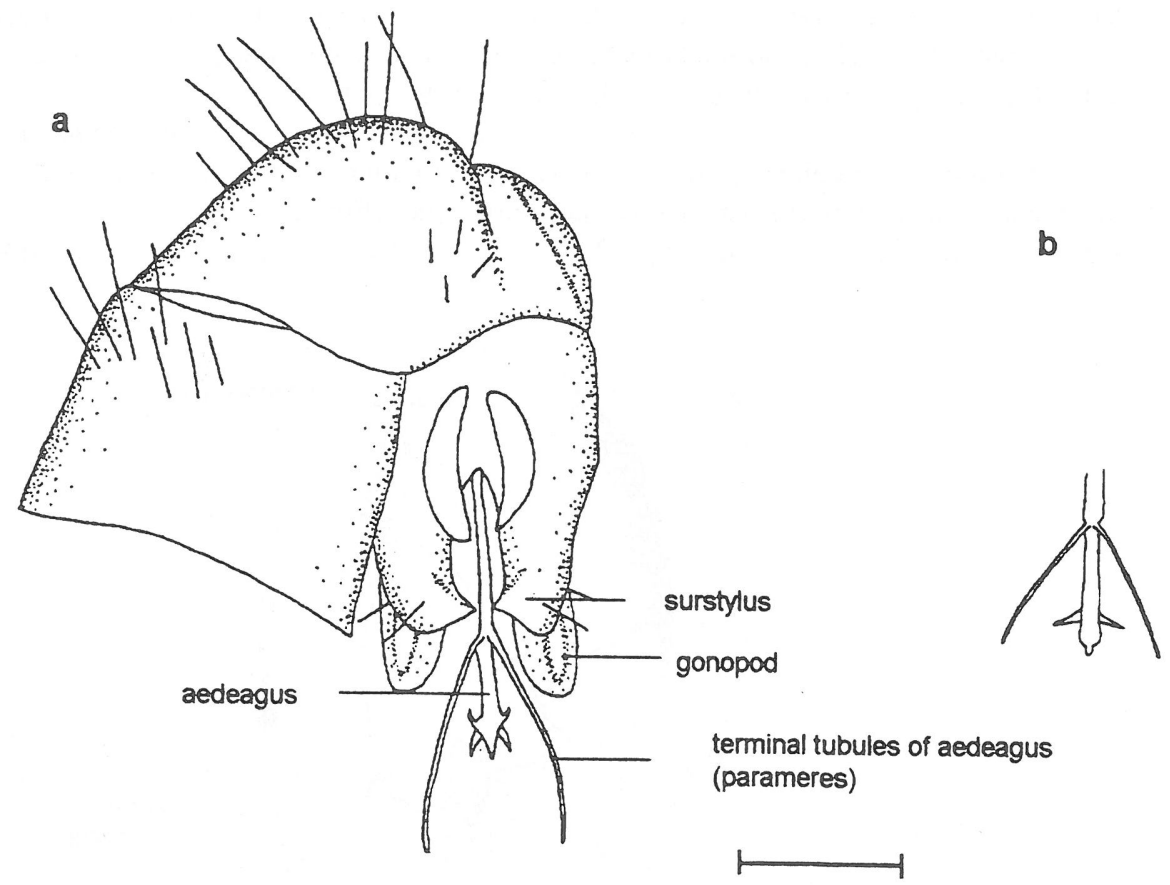

Fig. 1a: Chalarus decorus JERvis, 1992, male postabdomen showing epandrium from dorsal view; b: Chalarus spurius (FAlléN, 1816), distal part of aedeagus (scale $=0.1 \mathrm{~mm}$ ). Terminology after JeRVIS 1992.

Diagnosis: Wing length $2.20-2.93 \mathrm{~mm}$. Frons lacking fronto-orbital setae, mesonotum densely covered with hairs longer than orbital bristles. Legs and halteres normally dark brown. Apical setae of hind femora rather short and slightly curved. Abdomen rather broad: WT/LT $=0.79$ $1.08, \mathrm{LM} / \mathrm{WT}=0.44-0.56$. (abbreviations: WT: width of tergite $1 ; \mathrm{LT}$ : length of tergites 1-3 from dorsal view; LM: length of longest lateral marginal seta). Terminalia (Fig. 1a): Surstyli with ventral process, apical process of aedeagus slender and long. Acuminate processes of aedeagus twice as long as distiphallus.

The key of male Chalarus by JERviS (1992: 342) may be supplemented as follows:

Distiphallus with acuminate processes only slightly longer (1.15 times) than most sclerotized part of terminal tubules of ejaculatory duct (Fig. 1b; JERVIS: Fig. 37 D, p. 326). Surstyli with ventral process (JERVIS: Fig. 34 E, p. 319). . . spurius (FALLÉN) Distiphallus with acuminate processes, at least 1.5 times as long as most sclerotized part of terminal tubules of ejaculatory duct (JERVIS: Fig. 37 B, C, E) … . . 8

Surstyli with ventral process (JERVIS: Fig. 34 E) . . . . . . . . . . . 8 8 Surstyli without ventral process (JERVIS: Fig. 34 B-D). Terminal tubules of ejaculatory duct not divergent (fused by a membrane along their lengths, the pair displaced to one side, one process appearing longer than the other), covered in short, inconspicuous setae (Jervis: Fig. 37 B, C). Surstyli as in Jervis: Fig. 37 C . . . . . . . . . . . 9 
8a Distiphallus with acuminate processes broad and feather-shaped, 1.5 times as long as most sclerotized part of terminal tubules of ejaculatory duct, divergent, not covered in setae (Jervis: Fig. 37 E). Surstyli as in Jervis: Fig. 34 E . . . . . . . . . . . . .

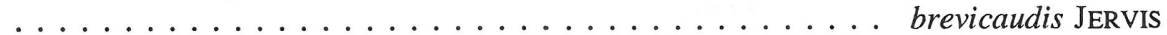

Distiphallus with acuminate processes slender and tubular, about twice as long as most sclerotized part of terminal tubules of ejaculatory duct (Fig. 1a).

Surstyli as in (Fig. 1a; JeRvis: Fig. 34 E) . . . . . . . . . decorus JeRvis

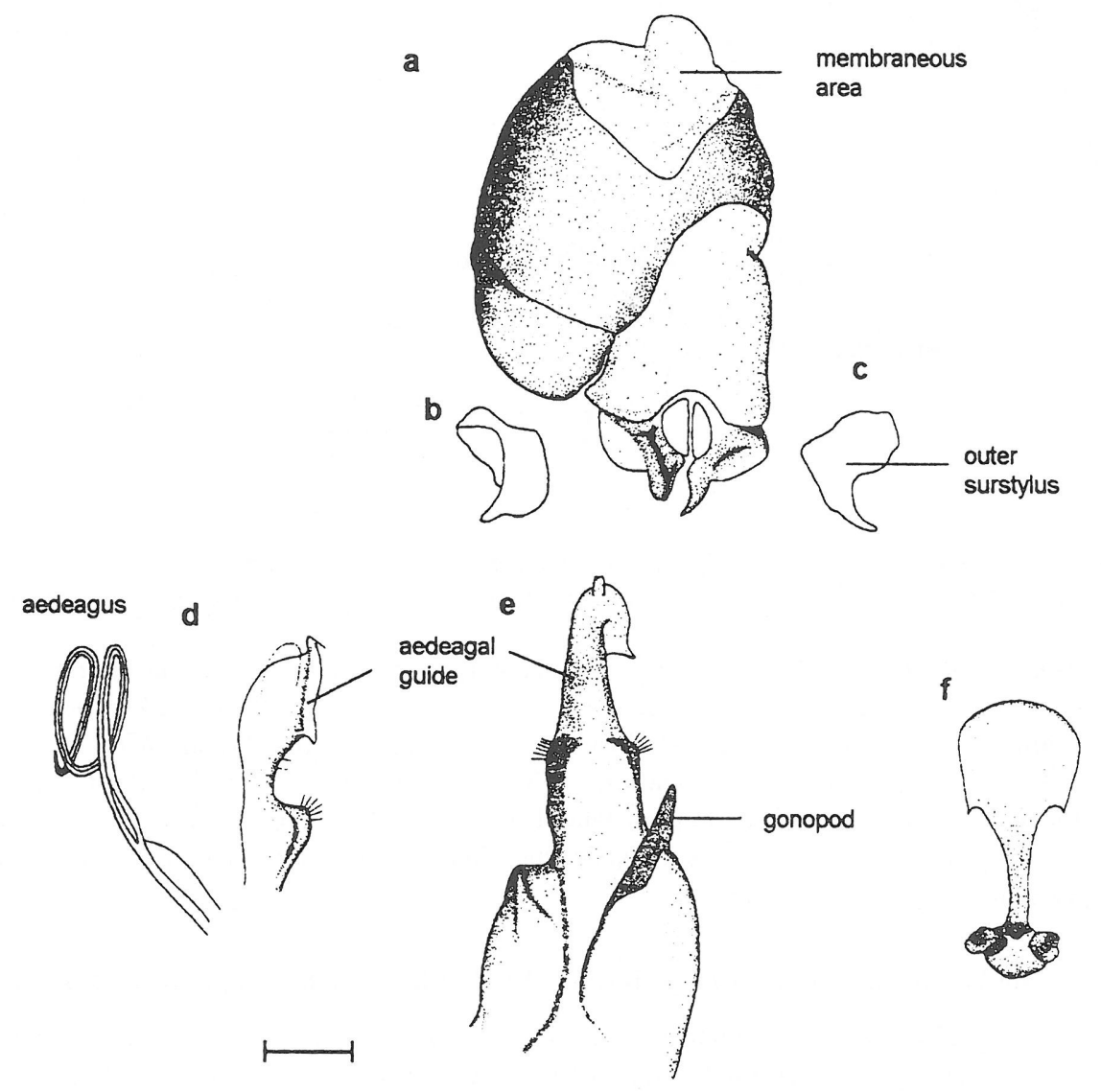

Fig. 2: Eudorylas subfascipes ColLIN, 1956, male terminalia - a: male postabdomen showing epandrium from dorsal view; b-c: surstyli, lateral view; d: hypandrium and aedeagus, lateral view; e: distal part of hypandrium, ventral view; f: ejaculatory apodeme (scale: $a-c=0.2 \mathrm{~mm}$; d-f $=0.1 \mathrm{~mm}$ ).

\section{Faunistical note}

Two malaise trap year cycles in the quarry (see above) yielded 104 specimens. The locality was surrounded by broom bushes and some young deciduous trees. Meanwhile the species was found in smaller numbers at many, sometimes quite different, localities. The specimens' temporal distribution in the weekly emptied malaise traps makes two generation per annum most evident, first from May till the middle of June and the second from July till August (for details DEMPEWOLF \& CÖLLN 1995). 
Eudorylas vonderdunki spec. nov.

(Fig. 3)

Diagnosis: This species can be easily identified by the yellow humeri, the colour of legs, the membraneous area. To avoid confusions with E. subfascipes CoLlin, 1956 the paler humeri and the shape of the male genitalia (Fig. 3) should be considered. The latter species is be related to $E$. vonderdunki although there are many differences: The humeri of both sexes of $E$. subfascipes are rather brown than yellow, the membraneous area is smaller, the aedeagus shorter and the surstyli are of similar shape but less elongated. Both species share the character of the strongly asymmetrical gonopods.
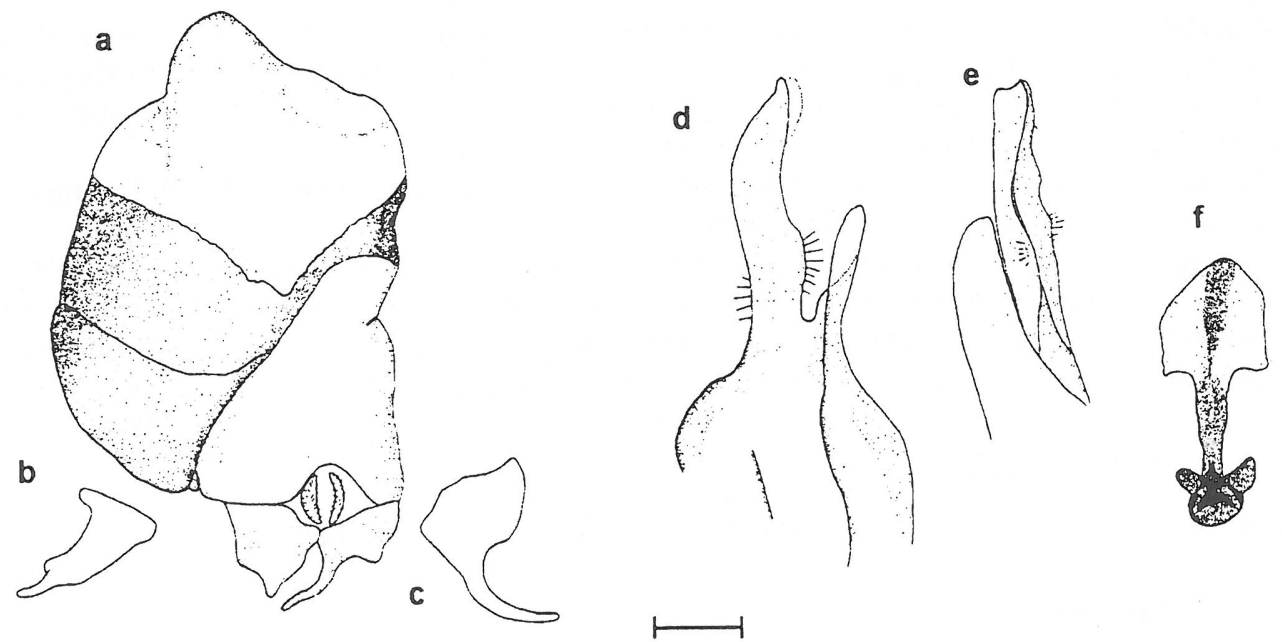

Fig. 3: Eudorylas vonderdunki spec. nov. male terminalia - a: male postabdomen showing epandrium from dorsal view; b-c: surstyli, lateral view; d-e: distal part of hypandrium, $\mathbf{d}$ ventral, e lateral; f: ejaculatory apodeme (scale: $\mathrm{a}-\mathrm{c}=0.2 \mathrm{~mm}$; $\mathrm{d}-\mathrm{f}=0.1 \mathrm{~mm}$ ).

Description: Male: Wing length 4.6 -5.2 mm Body length 4.1 - $4.8 \mathrm{~mm}$. Head: second antennal segment black, with short black hairs below and above; arista black, yellowish at base; third antennal segment rather short, acuminate, yellowish-brown at basal part, distalwards gradually getting paler. Junction of the eyes about twice as long as frontal triangle, both, the latter and face completely silvery dusted. Occiput covered with greyish pubescence, dorsal less pronounced than ventral. Thorax: Humeri clear yellow, mesonotum and scutellum brownish dusted, at the hind margin of scutellum several weak brown hairs which are upwards directed. Legs: Mainly greyish dusted except inner surface of hind femora. Coxae black, trochanters brownish, femora mainly black, the first four femora narrowly yellow at base and tip; at hind femora yellow colour occupies about the basal third. Mid femora with two rows of spinules on the inner sites. Hind tibiae completely yellow, the first four ones with inconspicuous brown coloration at distal two thirds especially in ventral view; apical spurs well developed at tarsi 1 \& 2 . Tarsi apart from the apical segment completely yellow, pulvilli about as long as last tarsomere. Wings: Pterostigma completely infuscated about as long as the following costal section.

Abdomen: First tergite with about five dark setae on each side. All terga brownish dusted on the dorsal surface the sides with greyish or silvery pubescence, without clear triangular spots. Tergite 5 at the posterior and ventral corner silvery dusted. Sternites brownish with yellow 
stripes at posterior margins. At syntergosternite 8 dorsal depression on the right side weakly developed, extending not more than to the basal quarter of the segment. Membraneous area very large (Fig. 3a), distance to the basal part of epandrium remarkable short. Epandrium reddish, distinctly paler than syntergosternite 8 and 7th sternite. Genitalia: Surstyli strongly asymmetrical, the outer one longer, strongly bent inwards (Fig. 3c). Hypandrium as shown in Figs 3d-e; aedeagal guide rather simple, inner gonopod completely reduced whereas the outer one is enlarged. Aedeagus trifid, very long, helical, longer than in E. subfascipes (not figured). Ejaculatory apodeme as shown in Fig. 3f.

Female: unknown.

Etymology: The species is named after the dipterist Dr. KLAUS VON DER DUNK (Nuremberg, Germany) who greatly increased our knowledge on the German pipunculid fauna.

Material: Holotype: Germany, Bavaria, Nuremberg forest near Günthersbühl, malaise trap, 14.VIII.1991, leg. M. Kram. Paratypes: same locality, 24.VIII.1991; 26 ơ ơ same locality and year as holotype. The series, except five specimens, which remained in the authors' collection, is deposited in the Alexander Koenig Museum (ZFMK) Bonn, Germany.

The specimens of Eudorylas subfascipes used for the drawings come from Rhineland-Palatinate, Germany (see DEMPEWOLF \& CöLLN 1995).

Discussion: The tip of the male abdomen of Eudorylas subfascipes was figured by COE (1966), ACKLAND (unpubl.) provided more detailed drawings of the genitalia. There are no conflicts to my specimens from Germany whereas Eudorylas vonderdunki spec. nov. is characterised by a remarkable larger membraneous area and different shape of aedeagal guide.

\section{Acknowledgements}

I like to thank Dr. MiCHAEL VON TSCHIRNHAUS (Bielefeld) for critical reading the manuscript.

\section{References}

ACKLAND, M. 1994 unpublished: Draft key to Eudorylas.

ALBRECHT, A. 1990: Revision, phylogeny and classification of the genus Dorylomorpha (Diptera, Pipunculidae). - Acta Zoologica fennica, Helsinki 188: 1-240.

COE, R. L. 1966: Diptera Pipunculidae. - Handbooks for the identification of British insects. - London: Royal Ent. Soc. London 10(2c): 83 pp.

Cumming, J. M.; Sinclair, B. J. \& Wood, D. M. 1995: Homology and phylogenetic implications of male genitalia in Diptera - Eremoneura. - Entomologica scandinavica, Copenhagen 26: 120-151.

De MeYer, M. 1989: The West-Palaearctic species of the pipunculid genera Cephalops and Beckerias (Diptera): classification, phylogeny and geographical distribution. - Journal of natural History, London 23: $725-765$.

DeMPewolf, M. \& Cölln, K. 1995: Augenfliegen (Diptera: Pipunculidae) von Gönnersdorf (Kr. Daun). Beiträge zur Insektenfauna der Eifeldörfer XV. - Dendrocopos, Trier 22: 126-148.

DEMPEWOLF, M. 1996: Taxonomical notes on west palaearctic Pipunculidae including the description of two new Eudorylas species (Diptera). - Studia dipterologica, Halle (Saale) 3(1): 87-92.

GRIFFITHS, G. C. D. 1996: Review of papers on the male genitalia of Diptera by D. M. Wood and associates. - Studia dipterologica, Halle (Saale) 3(1): 107-123.

JERVIS, M. A. 1992: A taxonomic revision of the pipunculid fly genus Chalarus WALKER, with particular reference to the European fauna. - Zoological Journal of the Linnean Society, London 105: 243-352.

MCALPINE, J. F. 1981: Morphology and Terminology - Adults. - pp. 9-37. - In: J. F. MCALPINE et al. (Eds): Manual of Nearctic Diptera. Volume I: Gess: Research Branch Agriculture Canada [Monograph No. 27], Ottawa. 
Morakote, R. \& Hirashima, Y. 1990a: A systematic study of the Japanese Pipunculidae (Diptera). Part II. The genus Chalarus WALKer. - Journal of the Faculty of Agriculture, Kyushu University, Fukuoka 34(3): 161-181.

Morakote, R. \& Hirashima, Y. 1990b: A systematic study of the Japanese Pipunculidae (Diptera). Part IV. The genus Pipunculus LATreILLE. - Journal of the Faculty of Agriculture, Kyushu University, Fukuoka 34 (3): 215-239.

RAfael, J. A. 1991: Espécies de Eudorylas AcZÉL do Peru (Diptera: Pipunculidae). - Boletim do Museu paraense Emilio Goeldi (Series Zoologia), Belem 7: 151-161.

RAFAEL, J. A. \& DE MEYER, M. 1992: Generic classification of the family Pipunculidae (Diptera): A cladistic analysis. - Journal of natural History, London 26(3): 637-658.

\author{
Author's address: \\ MARTIN DEMPEWOLF \\ Universität Bielefeld \\ Fakultät für Biologie, W0-320 \\ Postfach 100131 \\ D-33501 Bielefeld
}

\title{
Besprechungen
}

KLIMASZEWSKI, J. \& WATT, C.J.: Coleoptera: family-group review and keys to identification. - Lincoln (N. Z.): Manaaki Press, 1997. - 199 S.: 260 figs. - (Fauna of New Zealand; 37). - \$49.50

Dieser achte Beitrag über Käfer in der Reihe "Fauna of New Zealand" bringt eine Übersicht der in Neuseeland vertretenen 82 Familien mit zwei unterschiedlichen Bestimmungstabellen zu den Familien. Vorangestellt ist eine Checklist, die in übersichtlicher Form für jede Familie die Anzahl der neuseeländischen Gattungen, die Zahl der autochthonen Arten und die Zahl der Adventivarten enthält. Ein > vor der Artenzahl weist auf den noch immer schlechten Erforschungs- oder Bearbeitungsstand hin; das Zeichen findet sich immerhin bei der Artenzahl von 17 Familien, darunter so artenreichen wie Curculionidae und Staphylinidae. Die jetzt ausgewiesenen Gesamtzahlen von 1100 Gattungen, > 5223 autochthonen Arten und $>356$ Adventivarten werden sich in Zukunft noch beträchtlich erhöhen. Die Systematik orientiert sich an den Arbeiten von LAWRENCE \& NeWTON (1995) und PAKALUK \& al. (1994).

Einem allgemeinen Kapitel über die neuseeländische Käferfauna folgen Ausführungen über die Morphologie und Biologie, über Sammelmethoden und die zum Studium neuseeländischer Käfer wichtigste Literatur. Bei der Abhandlung der Familien wird jeweils auf die ausgezeichneten Habitus-Abbildungen repräsentativer Arten verwiesen und eine kurze Diagnose gegeben. Danach folgen Synopsis, kurze Verbreitungsübersicht für Neuseeland, Beispiele und Anmerkungen, bei einigen Familien, z. B. Carabidae und Staphylinidae, noch ein Schlüssel zu den Unterfamilien.

In Anhängen werden die gefährdeten Arten, die wichtigen entomologischen Sammlungen in Neuseeland, ein Schlüssel zu den Triben der Carabidae und die Verbreitung der Käferfamilien in den verschiedenen Neuseeländischen Territorien angegeben.

Das Buch entspricht etwa dem Band 1 des FreUde/HARDE/Lohse "Die Käfer Mitteleuropas" und bildet die Basis für die Beschäftigung mit der neuseeländischen Käferfauna. Es wirkt etwas moderner als der genannte Band 1; es erscheint aber auch 32 Jahre später, in denen die Käfersystematik gewaltige Fortschritte gemacht hat. Es bleibt zu hoffen, daß in der bewährten Reihe "Fauna of New Zealand" weitere Bände entstehen mögen, die zur Verbesserung der Kenntnisse über Neuseelands Käfer beitragen werden. Daß es - ähnlich wie in Mitteleuropa - in überschaubarer Zeit ein vollständiges Bestimmungswerk geben wird, ist nicht zu erwarten.

L. ZERCHE 